\title{
Plasma cytokines, glomerular filtration rate and adipose tissue cytokines gene expression in chronic kidney disease (CKD) patients
}

\author{
B. Spoto, D. Leonardis, R.M. Parlongo, P. Pizzini, A. Pisano, S. Cutrupi, \\ A. Testa, G. Tripepi, C. Zoccali*, F. Mallamaci
}

Nephrology, Dialysis and Transplantation Unit and CNR-IBIM Clinical Epidemiology and Pathophysiology of Renal Diseases and Hypertension, Reggio Calabria, Italy

Received 26 August 2010; received in revised form 14 December 2010; accepted 7 January 2011 Available online 7 September 2011

\section{KEYWORDS \\ Adipose tissue; \\ Cytokines; \\ Gene expression; \\ Chronic kidney disease}

\begin{abstract}
Background and Aim: Systemic inflammation is a hallmark of chronic kidney disease (CKD) and obesity represents a major risk factor for CKD. We investigated the relationship between plasma interleukin-6 (IL-6) and tumour necrosis factor- $\alpha$ (TNF- $\alpha$ ) and the glomerular filtration rate (GFR) in 75 stage $2-5$ CKD patients.

Methods and Results: We studied the steady-state relationship between plasma and subcutaneous adipose tissue (SAT) gene expression of the same cytokines in 19 patients and in 17 wellmatched healthy subjects (HS) and compared SAT gene expression of these cytokines and of two additional cytokines (IL-1 $\beta$ and IL-8) in CKD patients and in HS.

Plasma IL-6 and TNF- $\alpha$ were higher in CKD patients than in HS $(P<0.001)$. IL- 6 was similarly increased in patients with mild, moderate and severe CKD and largely independent of the GFR $(r=-0.03, P=N S)$. TNF- $\alpha$ was inversely related to GFR, which was the first factor in rank ( $\beta=-0.37, P=0.001$ ) explaining the variability in TNF- $\alpha$ in CKD. SAT messenger RNA (mRNA) levels of IL-6, TNF- $\alpha$, IL- $\beta$ and IL- 8 were similar in CKD patients and in HS. Plasma and SAT mRNA levels of IL- 6 and TNF- $\alpha$ levels were largely unrelated.

Conclusions: Plasma IL- 6 rises early in CKD and does not show any further increase at more severe stages of CKD, whereas TNF- $\alpha$ is inversely associated with the GFR indicating a substantial difference in the dynamics of the relationship between these cytokines and renal function. Cytokines are not overexpressed in SAT in these patients, and circulating IL- 6 and TNF- $\alpha$ are dissociated from the corresponding mRNA levels in SAT, both in CKD patients and in HS. (c) 2011 Elsevier B.V. All rights reserved.
\end{abstract}

* Corresponding author. CNR-IBIM, Nephrology, Dialysis and Transplantation Unit, Ospedali Riuniti, c/o EUROLINE di Ascrizzi Vincenzo, Via Vallone Petrara 55-57, 89124 Reggio Calabria, Italy. Tel.: +39 0965 397010; fax: +39 096526879.

E-mail address: carmine.zoccali@tin.it (C. Zoccali). 


\section{Introduction}

It is now well recognised that even a mild-to-moderate degree of kidney dysfunction predisposes an excess risk for cardiovascular (CV) complications [1,2]. Although in the general population traditional risk factors, such as hypertension, diabetes or dyslipidaemia, explain most of the excess risk for CV mortality, in chronic kidney disease (CKD) patients non-traditional risk factors, including inflammation, also have a relevant impact on survival and cardiovascular complications [3-6]. Inflammation is considered as a hallmark of CKD [7]. However, it is still undefined whether this alteration is an early correlate of glomerular filtration rate (GFR) loss or if it is a late phenomenon associated with severe impairment of the GFR.

Obesity is currently considered as one of the most relevant risk factors for CKD [8-10], and in the Framingham Offspring study both visceral and subcutaneous adiposity appeared to be associated with CKD [11]. Body fat excess is associated with a chronic inflammatory response characterised by abnormal cytokine production, increased acutephase reactants and the activation of pro-inflammatory signalling pathways encompassing interleukin-6 (IL-6) and tumour necrosis factor- $\alpha$ (TNF- $\alpha$ ) [12-14]. Such an association is causal in nature because even a small reduction in body weight is accompanied by a decrease in the expression of gene coding for inflammation proteins in obese individuals [15]. Also plasma C-reactive protein (CRP) falls considerably in proportion to body weight decrease after dietary or bariatric surgery interventions [16]

Although the adipose tissue is an established major source of inflammatory cytokines, the question whether fat excess contributes to the inflammatory state of CKD is still undefined. A study confined to 15 women on chronic dialysis treatment reported an enhanced expression of TNF- $\alpha$ but not of IL-6 in subcutaneous and visceral adipose tissue [17]. However, dialysis patients form a small and highly selected segment of the CKD population and survival to competing risk factors and nutritional disorders constitute objective limitations for generalising findings in this population of early and intermediate stages of CKD. The relationship between circulating and adipose tissue cytokines in pre-dialysis CKD, that is the largest segment of the CKD population and one of the most common chronic diseases with a worldwide prevalence of about $10 \%$, has never been investigated. With this background in mind, we studied the relationship between plasma cytokines and the GFR, and investigated the steadystate relationship between circulating and subcutaneous adipose tissue gene expression of cytokines, across the whole spectrum of CKD in a sizable series of CKD patients.

\section{Methods}

The study protocol conformed to the ethical guidelines of our institution, and informed consent was obtained from each participant.

\section{Patients and controls}

The measurement of the plasma concentrations of IL-6 and TNF- $\alpha$ was performed in 75 stage $2-5$ CKD incident patients referred to our unit. The causes of renal disease were: inherited renal disease in four patients [autosomal dominant polycystic kidney disease (ADPKD) in three and Alport syndrome in one]; interstitial nephritis in four; glomerulonephritis in 27; nephroangiosclerosis in 11; and unknown in 29. The mean age of the CKD patients was $52 \pm 16$ years (43 $\mathrm{M}$ and $32 \mathrm{~F}$ ). Twenty-one were obese (28\%), 28 were overweight (37\%) and the remaining 26 (35\%) had normal body weight. Thirteen patients had a history of major cardiovascular events (myocardial infarction/stroke). Thirty-six patients were habitual smokers and 69 patients (92\%) were on anti-hypertensive treatment. The main demographic, somatometric and clinical and biochemical characteristics of the patients included in the study are detailed in Table 1. As control subjects, we enrolled 33 healthy individuals accurately matched to patients in age, sex and BMI.

\section{Plasma cytokines}

In CKD patients and in controls, fasting blood sampling was performed early in the morning within $1 \mathrm{~h}$ of the surgical intervention, and plasma was stored at $-80{ }^{\circ} \mathrm{C}$ until analysis. Glomerular filtration rate was estimated (eGFR) using the Modification of Diet in Renal Disease (MDRD) formula derived by Levey et al. [18] All IL- 6 and TNF- $\alpha$ measurements were performed in duplicate by R\&D kits following the manufacturer's protocol.

\section{Gene expression studies}

The mRNA expression of inflammatory cytokines was measured in a group of 19 pre-dialysis CKD patients (obese, $n=3$ (16\%); overweight, $n=8$ (42\%); and normal weight patients, $n=8(42 \%)$ ) and 17 age, sex and BMI-matched healthy subjects (Table 2 ). In the 19 CKD patients, the causes of renal disease were: inherited renal disease in three patients (ADPKD in two and Alport syndrome in one); interstitial nephritis in four; glomerulonephritis in four; nephroangiosclerosis in two; and unknown in six. The two groups of CKD patients and healthy subjects (HS) were similar to the previously mentioned groups (CKD patients and controls where measurements of plasma cytokines were performed) for demographic and clinical characteristics.

Subcutaneous adipose tissue was harvested by periumbilical fat biopsy in three CKD patients and during elective surgery procedures both in remaining CKD patients (peritoneal dialysis catheter insertion in seven patients, renal biopsy in three, arteriovenous fistula positioning in five and cholecystectomy in one) and in healthy subjects (inguinal hernia in 12 patients, thyroidectomy in one, prostatic adenoma in one, anal fissure in one, pyeloureteral stenosis in one and hysterectomy for uterine fibroma in one).

Samples of adipose tissue were processed immediately after surgery to remove the stromal-vascular component from the adipose one, which was used for RNA extraction. Total RNA was isolated from adipose tissue finely chopped by hand using TRIzol reagent (Invitrogen, Carlsbad, CA, USA), following the manufacturer's instructions. Each RNA sample underwent a second extraction step by means of the Perfect RNA Mini Kit (Eppendorf, Hamburg, Germany), 
Table 1 Main clinical, biochemical and haemodynamic characteristics of CKD patients and HS who underwent plasma measurement of inflammatory cytokines.

\begin{tabular}{|c|c|c|c|}
\hline & $\begin{array}{l}\text { Normal subject } \\
(n=33)\end{array}$ & $\begin{array}{l}\text { CKD patients } \\
(n=75)\end{array}$ & $P$ \\
\hline \multicolumn{4}{|l|}{ Demographic data } \\
\hline Age (years) & $50 \pm 9$ & $52 \pm 16$ & 0.36 \\
\hline Male sex n. (\%) & $18(55 \%)$ & $43(57 \%)$ & 0.79 \\
\hline Smokers n. (\%) & $15(45 \%)$ & $36(48 \%)$ & 0.57 \\
\hline Diabetics n. (\%) & - & $13(17 \%)$ & - \\
\hline Patients with previous AMI/stroke n. (\%) & - & $13(17 \%)$ & - \\
\hline On anti-hypertensive treatment $\mathrm{n} .(\%)$ & - & 69 (92\%) & - \\
\hline BMI $\left(\mathrm{kg} / \mathrm{m}^{2}\right)$ & $28 \pm 4$ & $28 \pm 5$ & 0.87 \\
\hline \multicolumn{4}{|l|}{ BMI distribution } \\
\hline Normal weight $\left(\mathrm{BMI}<25 \mathrm{~kg} / \mathrm{m}^{2}\right) \mathrm{n} .(\%)$ & $7(21 \%)$ & $26(35 \%)$ & 0.35 \\
\hline Overweight (BMI ranging from 25 to $30 \mathrm{~kg} / \mathrm{m}^{2}$ ) n. (\%) & $16(49 \%)$ & $28(37 \%)$ & \\
\hline Obese $\left(\mathrm{BMI}>30 \mathrm{~kg} / \mathrm{m}^{2}\right) \mathrm{n} .(\%)$ & $10(30 \%)$ & $21(28 \%)$ & \\
\hline \multicolumn{4}{|l|}{ Office blood pressure } \\
\hline Systolic pressure (mmHg) & $122 \pm 17$ & $129 \pm 17$ & 0.03 \\
\hline Diastolic pressure (mmHg) & $80 \pm 7$ & $79 \pm 10$ & 0.43 \\
\hline Heart rate (beats/min) & $73 \pm 11$ & $73 \pm 11$ & 0.84 \\
\hline \multicolumn{4}{|l|}{ Biochemical data } \\
\hline Haemoglobin (g/dL) & $13.7 \pm 1.7$ & $12.5 \pm 1.8$ & 0.001 \\
\hline Cholesterol (mg/dL) & $186 \pm 36$ & $174 \pm 40$ & 0.15 \\
\hline Triglycerides (mg/dL) & $98 \pm 48$ & $155 \pm 84$ & $<0.001$ \\
\hline Albumin $(\mathrm{g} / \mathrm{dL})$ & $4.0 \pm 0.6$ & $3.9 \pm 0.6$ & 0.62 \\
\hline Creatinine $(\mathrm{mg} / \mathrm{dL})$ & $0.85 \pm 0.18$ & $2.83 \pm 1.56$ & $<0.001$ \\
\hline GFR $(\mathrm{ml} / \mathrm{min} / 1.73 \mathrm{~m} 2)(M D R D)$ & $91 \pm 13$ & $28.9 \pm 13.4$ & $<0.001$ \\
\hline Glucose $(\mathrm{mg} / \mathrm{dL})$ & $94.5 \pm 8.1$ & $99.9 \pm 24.4$ & 0.10 \\
\hline Calcium (mg/dL) & $9.1 \pm 0.5$ & $9.0 \pm 1.0$ & 0.50 \\
\hline Phosphate (mg/dL) & $3.1 \pm 0.4$ & $4.0 \pm 1.1$ & $<0.001$ \\
\hline
\end{tabular}

Data are expressed as mean $\pm \mathrm{SD}$, or as a percentage of frequency, as appropriate.

according to the manufacturer's instructions. Total RNA was treated with the DNA-free kit (Ambion, Austin, TX, USA) to digest contaminating genomic DNA. The integrity of the RNA samples was ascertained on 1\% agarose gel, and the concentration was determined spectrophotometrically (NanoDrop 1000, Thermo Fisher Scientific Inc.). Singlestranded complementary DNA (cDNA) was synthesised using High-Capacity cDNA Reverse Transcription Kit (Applied Biosystems, Foster City, CA, USA) and then preamplified with TaqMan PreAmp Master Mix Kit (Applied Biosystems, Foster City, CA, USA) following the manufacturer's protocol.

Measurement of tissue cDNA levels was performed by real time polymerase chain reaction (RT-PCR) by use of a 7300 Real Time PCR System (Applied Biosystems, Foster City, CA, USA). Pre-validated TaqMan Gene Expression Assays from Applied Biosystems were used to test the expression of $18 \mathrm{~S}, \mathrm{IL}-1 \mathrm{~b}, \mathrm{IL}-6, \mathrm{IL}-8$ and TNF- $\alpha$ genes (18S, Hs99999901-s1; IL-1b, Hs Hs00174097-m1; IL-6, Hs00174131m1; IL-8, Hs00174103-m1; and TNF- $\alpha$, Hs00174128-m1; Applied Biosystems). The RT-PCR was performed separately for each gene and all genes were run in triplicate. Controls with no template cDNA were introduced in each plate. The increase of fluorescence was measured in real time and data were obtained as threshold cycle $(C t)$ values.
To compensate for variation in input RNA amounts and efficiency of enzymatic reactions, the 'housekeeping' gene $18 \mathrm{~S}$ was used as a reference gene. The relative quantification value of the target genes IL-1 $1 \beta$, IL- 6 , IL- 8 and TNF$\alpha$ was calculated using the comparative $C t$ (threshold cycle) method and expressed as $2^{-\Delta \Delta C t}$ (fold difference) [19]).

\section{Statistical analysis}

Data are expressed as mean \pm SD (normally distributed data); geometric mean and range (not normally distributed data); or as percentage frequency. Comparisons between two groups were made by $T$-Test, Mann-Whitney $U$ test or chi-squared test, as appropriate. The strength of the association between two continuous variables was assessed by Pearson product moment correlation coefficient and $P$ value. Variables that showed a positively skewed distribution were $\log$ transformed $\left(\lg _{10}\right)$ before the correlation study.

The independent relationship between inflammatory cytokines and eGFR in CKD patients, was identified by multiple linear regression analysis adjusting for all potential confounders. That is (1) variables which were related to both exposure (eGFR) and study outcomes (inflammatory cytokines) with $P<0.10$; (2) which were not an effect of the 
Table 2 Main clinical, biochemical and haemodynamic characteristics of CKD patients and HS who underwent mRNA measurement of inflammatory cytokines.

\begin{tabular}{|c|c|c|c|}
\hline & Healthy subjects $(n=17)$ & CKD patients $(n=19)$ & $P$ \\
\hline \multicolumn{4}{|l|}{ Demographic data } \\
\hline Age (years) & $53 \pm 15$ & $52 \pm 14$ & 0.82 \\
\hline Male sex n. (\%) & $13(77 \%)$ & $12(63 \%)$ & 0.39 \\
\hline Smokers n. (\%) & $10(58 \%)$ & $10(53 \%)$ & 0.71 \\
\hline Diabetics n. (\%) & - & $2(11 \%)$ & - \\
\hline Patients with previous AMI/stroke n. (\%) & - & $2(11 \%)$ & - \\
\hline On anti-hypertensive treatment $\mathrm{n} .(\%)$ & - & $14(74 \%)$ & - \\
\hline $\mathrm{BMI}\left(\mathrm{kg} / \mathrm{m}^{2}\right)$ & $26 \pm 3$ & $26 \pm 4$ & 0.98 \\
\hline \multicolumn{4}{|l|}{ BMI distribution } \\
\hline Normal weight $\left(\mathrm{BMl}<25 \mathrm{~kg} / \mathrm{m}^{2}\right) \mathrm{n}$. (\%) & $6(35 \%)$ & $8(42 \%)$ & 0.81 \\
\hline Overweight (BMI ranging from 25 to $30 \mathrm{~kg} / \mathrm{m}^{2}$ ) n. (\%) & $9(53 \%)$ & $8(42 \%)$ & \\
\hline Obese $\left(\mathrm{BMI}>30 \mathrm{~kg} / \mathrm{m}^{2}\right) \mathrm{n} .(\%)$ & $2(12 \%)$ & $3(16 \%)$ & \\
\hline \multicolumn{4}{|l|}{ Office blood pressure } \\
\hline Systolic pressure (mmHg) & $122 \pm 13$ & $129 \pm 21$ & 0.27 \\
\hline Diastolic pressure $(\mathrm{mmHg})$ & $72 \pm 9$ & $77 \pm 10$ & 0.18 \\
\hline Heart rate (beats/min) & $69 \pm 8$ & $71 \pm 10$ & 0.60 \\
\hline \multicolumn{4}{|l|}{ Biochemical data } \\
\hline Haemoglobin (g/dL) & $14.4 \pm 1.7$ & $11.7 \pm 1.4$ & $<0.001$ \\
\hline Cholesterol (mg/dL) & $194 \pm 30$ & $179 \pm 43$ & 0.29 \\
\hline Triglycerides (mg/dL) & $101 \pm 43$ & $129 \pm 44$ & 0.07 \\
\hline Albumin $(\mathrm{g} / \mathrm{dL})$ & $4.4 \pm 0.5$ & $4.1 \pm 0.5$ & 0.11 \\
\hline Creatinine $(\mathrm{mg} / \mathrm{dL})$ & $0.91 \pm 0.14$ & $6.66 \pm 4.32$ & $<0.001$ \\
\hline GFR $\left(\mathrm{ml} / \mathrm{min} / 1.73 \mathrm{~m}^{2}\right)$ & $89 \pm 14$ & $14 \pm 12$ & $<0.001$ \\
\hline Glucose (mg/dL) & $91 \pm 9$ & $85 \pm 13$ & 0.11 \\
\hline Calcium (mg/dL) & $9.1 \pm 0.5$ & $8.9 \pm 1.0$ & 0.62 \\
\hline Phosphate (mg/dL) & $3.2 \pm 0.7$ & $5.4 \pm 1.7$ & $<0.001$ \\
\hline
\end{tabular}

Data are expressed as mean \pm SD or as a percentage of frequency, as appropriate.

exposure; and (3) that were not in the causal pathway between the exposure and outcomes [20]. Data are expressed as a standardised regression coefficient $(\beta)$ and $P$ value.

Segmented linear regression analysis (breakpoint analysis) [21] was performed to establish whether the GFR inflammation biomarkers relationships were linear or nonlinear and if a breakpoint in eGFR exists that minimises the residual sum of squares of these relationships. The breakpoint analysis was carried out using standard, freely downloadable statistical software (SegReg program, available on the website http://www.waterlog.info/segreg.htm). All calculations except breakpoint analysis were carried out using Statistical Package for Social Sciences (SPSS) for Windows Version 9.0.1, 11 March 1999, Chicago, IL, USA.

\section{Results}

Demographic, somatometric clinical and biochemical data of the main study population are reported in Table 1 . The average systolic pressure was $7 \mathrm{mmHg}$ higher in CKD patients than in HS. Moreover, CKD patients had lower haemoglobin and higher serum triglycerides and phosphates when compared with HS (Table 1). No difference was observed between CKD patients and HS in the distribution of BMI classes (Table 1). IL-6 and TNF- $\alpha$ were significantly higher in CKD patients than in HS (Fig. 1).

\section{Plasma levels of inflammatory cytokines and renal function in CKD patients and in HS}

Plasma levels of IL-6 similarly increased in patients with mildto-moderate (stage 2-3 CKD) (geometric mean: $1.24 \mathrm{pg} \mathrm{ml}^{-1}$, range: $0.7-121 \mathrm{pg} \mathrm{ml}^{-1}$ ) and severe CKD (stage 4-5 CKD) (geometric mean: $1.70 \mathrm{pg} \mathrm{ml}^{-1}$, range: $0.7-78 \mathrm{pg}$ / $\left.\mathrm{ml}^{-1}\right)$ and largely unrelated to the eGFR $(r=-0.03, P=\mathrm{NS})$. By contrast, TNF- $\alpha$ was inversely related to eGFR in CKD patients $(r=-0.36, P=0.001)$, and, in an aggregate analysis, including CKD patients and HS the value of $81 \mathrm{ml} \mathrm{min}^{-1}$ $1.73 \mathrm{~m}^{-2}$ was identified as the threshold level below which TNF- $\alpha$ accumulates as the eGFR deteriorates (Fig. 2). In a multiple linear regression model in CKD patients, the eGFR was the first factor in rank $(\beta=-0.37, P=0.001)$ explaining the variability in plasma TNF- $\alpha$, followed by serum albumin ( $\beta=-0.24, P=0.03)$. Further data adjustment for serum cholesterol, diabetes, calcium, phosphate, antihypertensive treatment and previous CV events did not change these results (data not shown).

\section{Plasma and subcutaneous adipose tissue cytokines gene expression in CKD patients and HS}

Demographic, clinical and biochemical data in CKD patients and HS, who underwent simultaneous plasma and adipose 

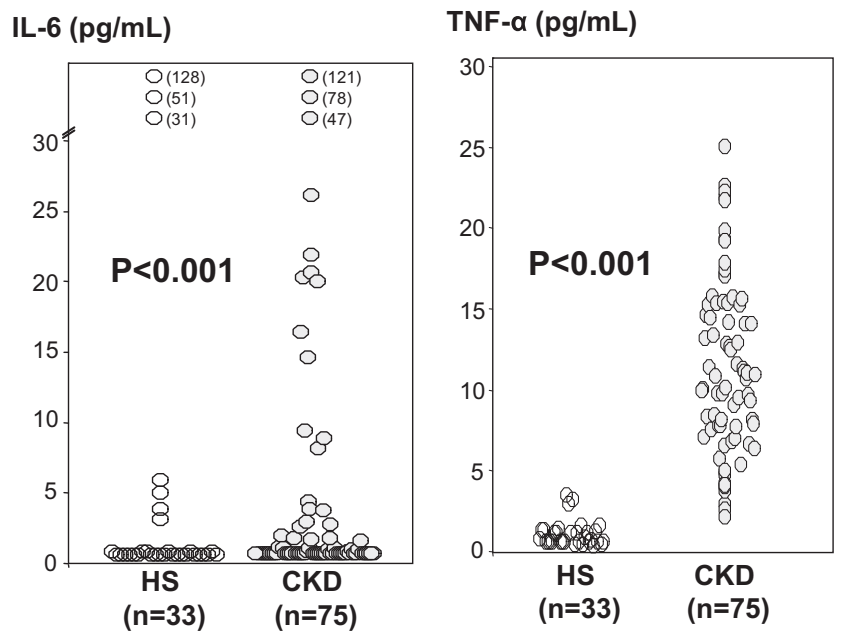

Figure 1 IL-6 and TNF- $\alpha$ plasma levels in CKD patients (grey circles) and healthy subjects (HS) (open circles).

tissue gene expression measurements, are summarised in Table 2. Even though IL-6 gene expression levels tended to be higher $(P=0.07)$ in CKD patients than in HS, the data distribution showed substantial overlapping between groups (Fig. 3). Similarly, the gene expression levels of TNF$\alpha$, IL-1 $\beta$ and IL- 8 did not differ and comparisons between CKD patients and HS for these cytokines were all largely non-significant (Fig. 3). In a combined analysis of CKD patients and HS, gene expression levels of IL- 6 and TNF- $\alpha$ in subcutaneous adipose tissue were unrelated to the corresponding plasma levels of these cytokines (Fig. 4), and this was also true in a separate analysis by gender ( $P$ ranging from 0.17 to 0.83 ). The underlying diagnosis of renal disease did not affect the relationship between plasma and gene expression levels of IL- 6 and TNF- $\alpha$ ( $P$ ranging from 0.31 to 0.52 ).

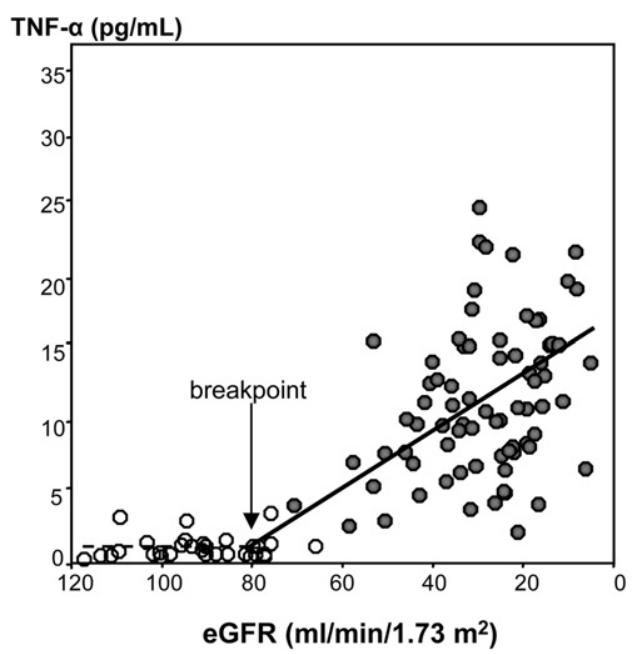

Figure 2 Relationship between GFR and TNF- $\alpha$ plasma levels in an aggregate analysis of CKD patients (grey circles) and healthy subjects (HS) (open circles). The breakpoint analysis of the regression line between TNF- $\alpha$ and GFR is also shown (see text for details).

\section{Discussion}

This study shows that plasma IL-6 undergoes an early increase in chronic nephropathies and does not show any further increase in moderate and severe CKD, whereas TNF$\alpha$ is inversely associated with eGFR indicating a substantial difference in the dynamics of the relationship between these cytokines and renal function. Furthermore, we show that these cytokines, as well as IL-1 $\beta$ and IL- 8 , are not overexpressed in subcutaneous adipose tissue in these patients and that circulating IL- 6 and TNF- $\alpha$ are dissociated from the corresponding mRNA levels in this adipose tissue compartment, both in CKD patients and in HS.

\section{Plasma levels of inflammatory cytokines and renal function}

A low-grade inflammation is recognised as a common feature of chronic renal failure. A significant increase in cytokine plasma levels was described in the mid-1990s by Descamps-Latscha et al., in patients with varying degrees of renal failure [22]. In the present study, we specifically focussed on the link between two major adipose tissue cytokines, IL- 6 and TNF- $\alpha$, and the severity of renal disease. We found that plasma levels of these cytokines were higher in stage 2-5 CKD patients than in control subjects, but differed substantially regarding their relationship with the GFR. Elevated IL-6 levels have been recently reported in CKD patients and were found to be predictive of clinical outcomes in this population [23]. Our finding that circulating levels of II-6 increase similarly in patients with mild-to-moderate and severe CKD would support the hypothesis that raised IL-6 in CKD, represents an early response to renal disease rather than a mere accumulation phenomenon attributable to loss of renal function. While plasma IL-6 evenly increased in CKD, plasma TNF- $\alpha$ was strictly GFR-dependent reaching the highest levels in severe CKD. Of note, by the application of breakpoint analysis, we identified $81 \mathrm{ml} \mathrm{min}^{-1} 1.73 \mathrm{~m}^{-2}$ as the GFR threshold below which this cytokine starts 

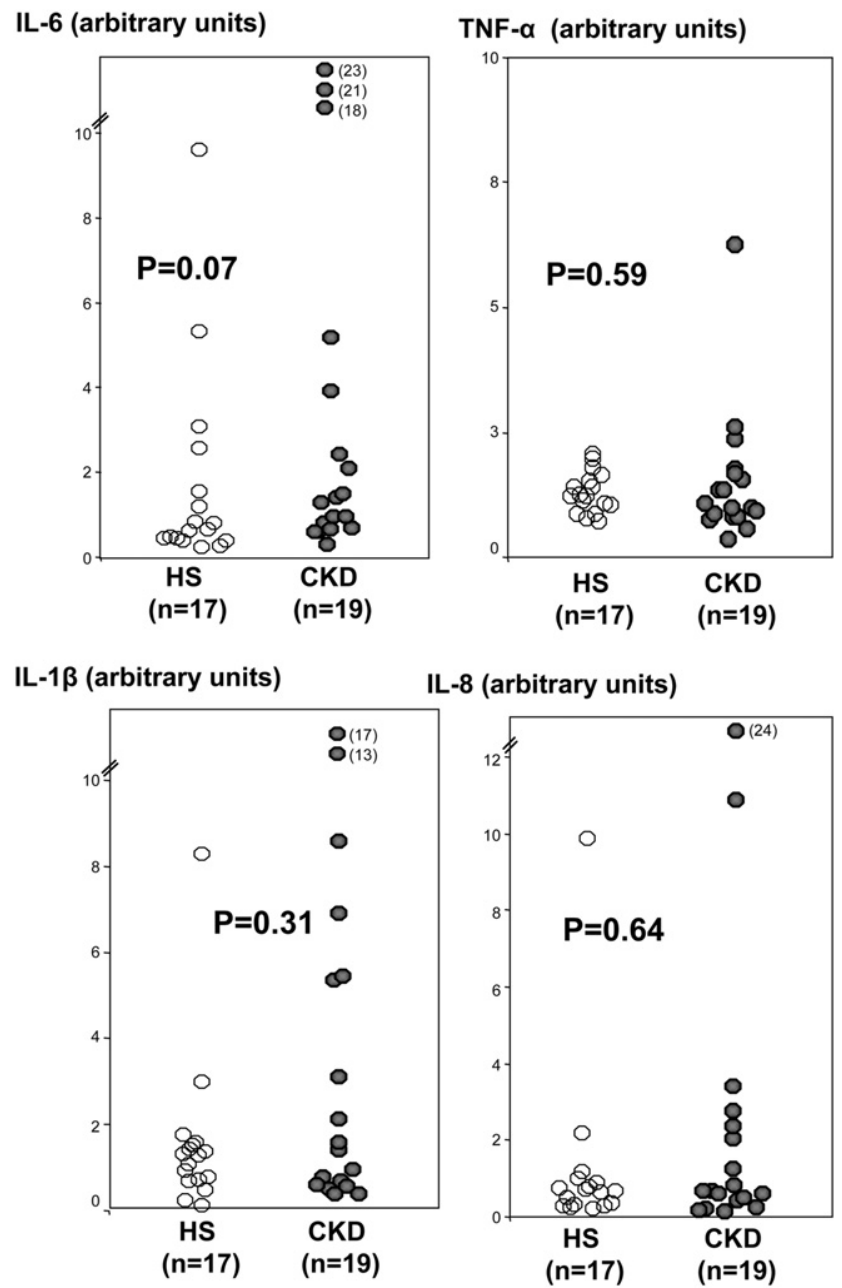

IL-8 (arbitrary units)

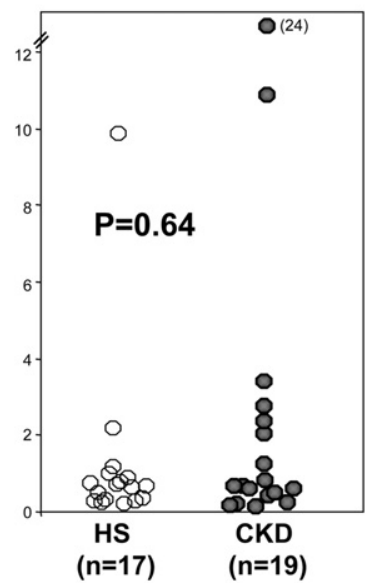

Figure 3 Gene expression levels of IL-6, TNF- $\alpha$, IL-1 $\beta$ and IL-8 in CKD patients (grey circles) and healthy subjects (HS) (open circles) who underwent simultaneous plasma and mRNA measurements of inflammatory cytokines.

accumulating in CKD. In this respect, our data are in keeping with experiments in mice, showing that the kidney is fundamental for TNF- $\alpha$ clearance [24,25]. Although the inflammatory role of TNF- $\alpha$ is well recognised, the fact that this cytokine, at least in part, reflects reduced renal clearance, makes it a questionable indicator of the severity of systemic inflammation in CKD.

\section{mRNA levels of inflammatory cytokines in adipose tissue}

Obesity is associated with inflammation and a meta-analysis of studies of body weight reduction, either by dietary or surgical interventions, coherently confirmed the proinflammatory effect of fat excess [16]. While confirming that plasma levels of IL- 6 and TNF- $\alpha$ are substantially increased in CKD patients, we for the first time also show that the gene expression of these pro-inflammatory cytokines, as well as those of two major cytokines such as IL$\beta$ and IL-8, are not up-regulated in the subcutaneous adipose tissue of CKD patients in comparison with age-, sex and BMImatched healthy controls. This indicates that overexpression of TNF- $\alpha$ in subcutaneous and visceral adipose tissue in women maintained on chronic dialysis [17] is a late phenomenon confined to end-stage renal disease and that it is highly unlikely that subcutaneous adipose tissue contributes to systemic inflammation in pre-dialysis CKD patients. Subcutaneous and visceral adipose tissues represent substantially different compartments of adipose mass regarding their relationship with metabolic risk factors [26]. It was shown that both subcutaneous and visceral adipose tissue are associated with CKD in the Framingham Offspring study [11], an epidemiological finding which agrees with recent findings in obese individuals where subcutaneous and visceral adipose tissue display analogous pro-inflammatory gene expression levels [27]. Even though these observations may suggest that our data in subcutaneous adipose tissue may be generalised to the corresponding visceral compartment, we believe that studies extended to visceral adipose tissue should be performed to complete the characterisation of the adipose tissue-inflammation link and to see whether a GFR threshold exists below which adipose tissue cytokines expression is up-regulated in CKD.

In conclusion, plasma IL-6 increases early in CKD and does not show any further increase at more severe stages of CKD, while TNF- $\alpha$ is inversely associated with the GFR indicating a substantial difference in the dynamics of the 

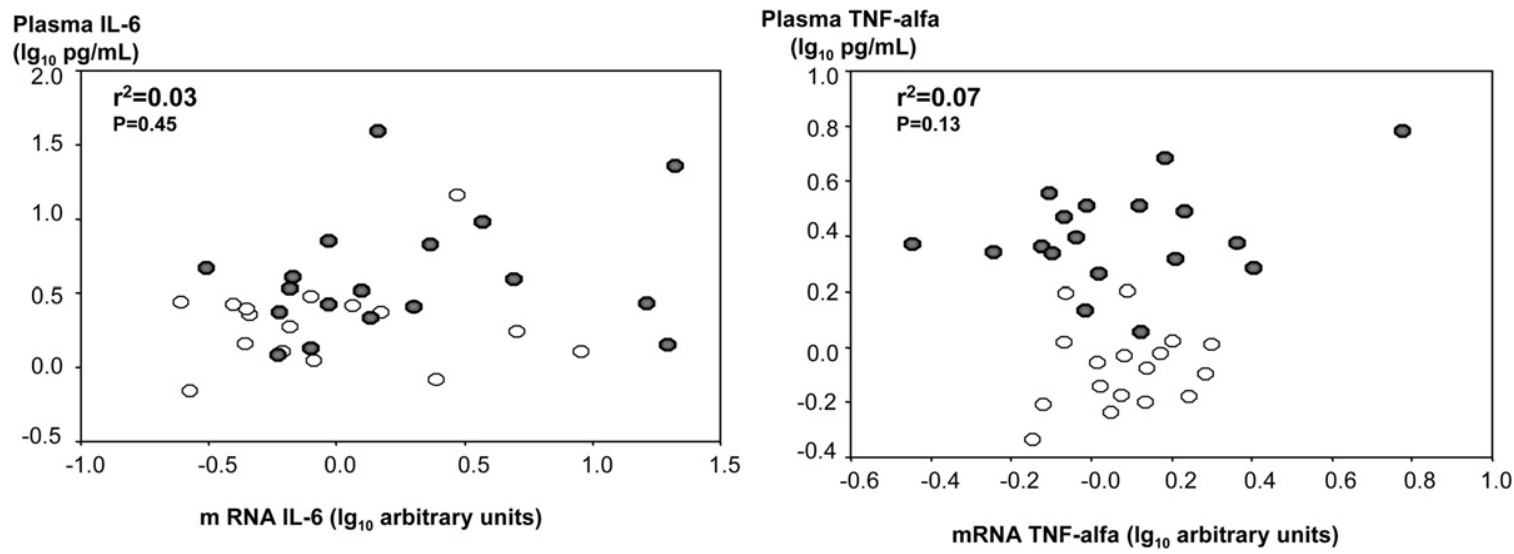

Figure 4 Relationships between circulating and adipose tissue gene expression levels of IL- 6 and TNF- $\alpha$ in CKD patients (grey circles) and healthy subjects (HS) (open circles) who underwent both plasma and mRNA measurements.

relationship of these cytokines with renal function. Furthermore, systemic inflammation in CKD patients appears to be a phenomenon largely independent from cytokines gene expression in subcutaneous adipose tissue in these patients. Inflammation in CKD may depend on diffuse activation of macrophages in the reticuloendothelial system rather than on augmented synthesis in adipocytes and/or macrophages in adipose depots. Whether an overproduction of cytokines confined to visceral adipose tissue contributes to raise IL- 6 and TNF- $\alpha$ in CKD is an issue deserving specific studies in this population.

\section{Acknowledgements}

This study was supported by a European Union grant from Framework Programme 7 (FP7) under the SysKid (Systems Biology towards Novel Chronic Kidney Disease Diagnosis and Treatment) project, by the Italian Ministry of Education, University and Research (MIUR), Project of Relevant National Interest (PRIN 2007).

\section{References}

[1] Sarnak MJ, Levey AS, Schoolwerth AC, Coresh J, Culleton B, Hamm LL, et al. American heart association councils on kidney in cardiovascular disease, high blood pressure research, clinical cardiology, and epidemiology and prevention. Kidney disease as a risk factor for development of cardiovascular disease: a statement from the American heart association councils on kidney in cardiovascular disease, high blood pressure research, clinical cardiology, and epidemiology and prevention. Circulation 2003;108:2154-69.

[2] Schiffrin EL, Lipman ML, Mann J. Chronic kidney disease: effects on the cardiovascular system. Circulation 2007;116:85-97.

[3] Stinghen AE, Bucharles S, Riella MC, Pecoits-Filho R. Immune mechanisms involved in cardiovascular complications of chronic kidney disease. Blood Purif 2010;29:114-20.

[4] Kendrick J, Chonchol MB. Nontraditional risk factors for cardiovascular disease in patients with chronic kidney disease. Nat Clin Pract Nephrol 2008;4:672-81.

[5] Zoccali C. Traditional and emerging cardiovascular and renal risk factors: an epidemiologic perspective. Kidney Int 2006; $70: 26-33$.
[6] Vidt DG. Inflammation in renal disease. Am J Cardiol 2006; 97:20A-7A.

[7] Stenvinkel P. New insights on inflammation in chronic kidney disease-genetic and non-genetic factors. Nephrol Ther 2006; 2:111-9.

[8] Ross WR, McGill JB. Epidemiology of obesity and chronic kidney disease. Adv Chronic Kidney Dis 2006;13:325-35.

[9] Mafra D, Guebre-Egziabher F, Fouque D. Body mass index, muscle and fat in chronic kidney disease: questions about survival. Nephrol Dial Transplant 2008;23:2461-6.

[10] Stenvinkel P, Ketteler M, Johnson RJ, Lindholm B, PecoitsFilho R, Riella M, et al. IL-10, IL-6, and TNF-alpha: Central factors in the altered cytokine network of uremia - the good, the bad, and the ugly. Kidney Int 2005;67:1216-33.

[11] Young JA, Hwang SJ, Sarnak MJ, Hoffmann U, Massaro JM, Levy D, et al. Association of visceral and subcutaneous adiposity with kidney function. Clin J Am Soc Nephrol 2008;3:1786-91.

[12] Wellen KE, Hotamisligil GS. Obesity-induced inflammatory changes in adipose tissue. J Clin Invest 2003;112:1785-8.

[13] Bastard JP, Jardel C, Delattre J, Hainque B, Bruckert E, Oberlin F. Evidence for a link between adipose tissue interleukin- 6 content and serum C-reactive protein concentrations in obese subjects. Circulation 1999;99:2221-2.

[14] Maachi M, Pieroni L, Bruckert E, Jardel C, Fellahi S, Hainque B, et al. Systemic low grade inflammation is related to both circulating and adipose tissue TNF $\alpha$, leptin and interleukin-6 levels in obese women. Int J Obes 2004;28:993-7.

[15] Clement K, Viguerie N, Poitou C, Carette C, Pelloux V, Curat CA, et al. Weight loss regulates inflammation-related genes in white adipose tissue of obese subjects. FASEB $\mathrm{J}$ 2004;18:1657-69.

[16] Selvin E, Paynter NP, Erlinger TP. The effect of weight loss on C-reactive protein. A systematic review. Arch Intern Med 2007;167:31-9.

[17] Roubicek T, Bartlova M, Krajickova J, Haluzikova D, Mraz M, Lacinova $Z$, et al. Increased production of proinflammatory cytokines in adipose tissue of patients with end-stage renal disease. Nutrition 2009;25:762-8.

[18] Levey AS, Greene T, Kusek JW, Beck GL. Modification of Diet in Renal Disease (MDRD) study group. A simplified equation to predict glomerular filtration rate from serum creatinine (abstract). J Am Soc Nephrol 2000;11:155A.

[19] Livak KJ, Schmittgen TD. Analysis of relative gene expression data using real-time quantitative PCR and the 2(-Delta Delta $C(T)$ ) method. Methods 2001;25:402-8.

[20] Jager KJ, Zoccali C, Macleod A, Dekker FW. Confounding: what it is and how to deal with it. Kidney Int 2008;73:256-60. 
[21] Zoccali C, Postorino M, Martorano C, Salnitro F, Maggiore Q. The 'breakpoint' test, a new statistical method for studying progression of chronic renal failure. Nephrol Dial Transplant 1989;4:101-4.

[22] Descamps-Latscha B, Herbelin A, Nguyen AT, Roux-Lombard P, Zingraff J, Moynot A, et al. Balance between IL-1 beta, TNFalpha, and their specific inhibitors in chronic renal failure and maintenance dialysis. Relationships with activation markers of T cells, B cells, and monocyte. J Immunol 1995;154:882-92.

[23] Barreto DV, Barreto FC, Liabeuf S, Temmar M, Lemke HD, Tribouilloy C, et al. European Uremic Toxin work group (EUTox). Plasma interleukin-6 is independently associated with mortality in both hemodialysis and pre-dialysis patients with chronic kidney disease. Kidney Int 2010;77:550-6.
[24] Bemelmans MH, Gouma DJ, Buurman WA. Influence of nephrectomy on tumor necrosis factor clearance in a murine model. J Immunol 1993;150:2007-17.

[25] Bemelmans MH, van Tits LJ, Buurman WA. Tumor necrosis factor: function, release and clearance. Crit Rev Immunol 1996;16:1-11.

[26] Wajchenberg BL. Subcutaneous and visceral adipose tissue: their relation to the metabolic syndrome. Endocr Rev 2000;21: 697-738.

[27] Dolinkova M, Dostalova I, Lacinova Z, Michalsky D, Haluzikova D, Mraz M, et al. The endocrine profile of subcutaneous and visceral adipose tissue of obese patients. Mol Cell Endocrinol 2008;291:63-70. 